\title{
Z nadzieją w kolejne lata strażników Piękna...
}

Oddajemy do Waszych rąk kolejny numer naszego czasopisma „Pro Musica Sacra”, tym razem w roku kanonizacji Jana Pawła II, patrona naszej uczelni, i Jemu właśnie chcemy dedykować to naukowe dzieło.

W tegorocznym wydaniu odnajdziemy ciekawe artykuły, m.in.: o aktualności odnowy muzyki kościelnej reformy Piusa X, o kategoriach muzycznego piękna w celebracji liturgicznej. Przywołujemy postacie i kompozycje Henryka Mikołaja Góreckiego, Bolesława Wallek-Walewskiego, a także działalność Oskara Kolberga, jak też przedstawiamy liturgiczną twórczość organową Kościoła. W dziale recenzji dowiemy się o serii płyt pt. Antologia Organów Archidiecezji Krakowskiej, o książce Laus in Ecclesia. Szkota śpiewu gregoriańskiego, a w sprawozdaniach przeczytamy o IX Dniach Muzyki Kościelnej w Archidiecezji Krakowskiej i o organach w kaplicy Wyższego Seminarium Duchownego Archidiecezji Krakowskiej. Te naukowe opracowania i wiadomości przywołują w pamięci ludzi i dzieła, które dzisiaj są aktualne dla rozwoju i popierania wartościowej muzyki kościelnej.

Międzyuczelniany Instytut Muzyki Kościelnej w Krakowie w roku akademickim 2014 był współorganizatorem międzynarodowej sesji naukowej i obchodów 650-lecia konsekracji katedry wawelskiej. Było to dla nas najważniejsze wydarzenie w naszej rocznej działalności. Dlatego też następny numer naszego czasopisma będzie poświęcony temu właśnie wydarzeniu i przypomni rolę tego szczególnego miejsca kultury, a w niej muzyki w świecie.

Papież Jan Paweł II w swoim Liście do artystów w 1999 roku pisał: „nikt nie potrafi zrozumieć lepiej niż wy, artyści, genialni twórcy piękna, czym był ów pathos, z jakim Bóg u świtu stworzenia przyglądał się dziełu swoich rąk" (Jan Paweł II, List do artystów, 1), a także: „Artysta świadomy wie, że musi działać, nie kierując się dążeniem do próżnej chwały ani żądzą taniej popularności, ani tym mniej nadzieją na osobiste korzyści" (Jan Paweł II, List do Artystów, 4). Chcemy więc tym właśnie - kolejnym numerem naszego pisma - wejść coraz bardziej w poznawanie Piękna i nie kierując się próżnością czy popularnością, stać na jego straży.

ks. dr hab. Robert Tyrała Redaktor naczelny „Pro Musica Sacra” 